\title{
Community participation in waste management
}

\author{
Lidia Br Tarigan ${ }^{1}$, Yuanita C. Rogaleli ${ }^{2}$, Ferry W.F Waangsir ${ }^{3}$ \\ ${ }^{1}$ Sanitation Study Program, Kupang Health Polytechnic, Ministry of Health, Indonesia \\ ${ }^{2}$ Lecture, Kupang Health Polytechnic, East Nusa Tenggara, Indonesia \\ ${ }^{3}$ Sanitation Study Program, Kupang Health Polytechnic, Ministry of Health, Indonesia
}

\begin{tabular}{l} 
Article Info \\
\hline Article history: \\
Received Nov 7, 2019 \\
Revised Apr 3, 2020 \\
Accepted Apr 28, 2020 \\
\hline Keywords: \\
Community participation \\
Population characteristics \\
Waste production
\end{tabular}

Waste production

\begin{abstract}
Improper management of waste can be a source of health and environmental problems. Community participation contributes to effective waste management. The study was aimed at analyzing community participation in waste management at Liliba Village in Kupang City. This research is an analytic study with cross sectional study approach. The population was the entire population of Liliba Village in Kupang City. There were 133 respondents participated in this study. The data were analyzed using the structural equation model test. Education and occupation had strong correlation and significant influence to community participation. Community participation had strong relation and significant effect on waste production. Population had weak correlation and insignificant effect on waste production. It is recommended that interventions should be done for invalid indicator such as of waste utilization in the form of counseling or training on waste recycling.
\end{abstract}

This is an open access article under the CC BY-SA license.

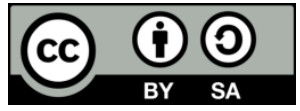

\section{Corresponding Author:}

Lidia Br Tarigan,

Sanitation Study Program,

Kupang Health Polytechnic Ministry of Health,

Jl. Piet A. TalloLiliba Kota Kupang Nusa Tenggara Timur, Indonesia.

Email: lidia.tarigan@gmail.com

\section{INTRODUCTION}

Waste is unusable, unwanted, or worthless materials that are discarded and it is derived from human activities not from its own nature [1]. Waste management is a shared responsibility. It is stated in government rule, PP no 81 of 2012 article 10 Paragraph 2 that "everyone is required to reduce and manage waste" [2]. Unmanaged waste can be a threat to public health [3]. Community participation is absolutely essential in implementing community-based waste management [4]. Community participation in waste management can be implemented through active involvement in the process of disposal, transportation, and waste management, with a sense of awareness and responsibility to create a clean and healthy environment [5]. Factors that can affect waste management are population characteristics (income, age of assets) [6], community participation, volume of waste and waste characteristics. Liliba Village still has waste management problems. People are still disposingwastein empty landandrivers, and burning garbage in the yard of their houses. Based on data from the Department of Environmental and Sanitation in Kupang city, Liliba Village has three temporary landfillswith a volume of 8 to 10 cubic meters. Landfills also need to be monitored regularly [7]. Not all people dispose their waste into temporarylandfills because the locations cannot be reached by them. The problem of waste in Liliba Village can be overcome by involving the community as a waste producer and with an integrated approach that combines a participatory approach in waste management [8]. 


\section{RESEARCH METHOD}

This is an analytic research and the data collection techniques were done through a cross sectional approach. The population was the whole population of Liliba Village in Kupang City. The total sample was 133 people. They were selected according to the minimum sample in SEM analysis where the number of sample should 5-10 times the analyzed indicators [9]. This study analyzed 11 indicators that are grouped into three factors such as population characteristics (level of education, occupation and income), community participation (providing bins, sorting waste, utilizing waste, disposing waste into temporary landfills and paying waste bill) and waste production (waste volume, organic and inorganic waste). Questionnaire was used to collect data. Measurement of waste production refers to SNI 19-3964-1994 about the method of taking and measuring examples of the generation and composition of urban waste [10]. Data were analyzed using the structural equation model (SEM) test [11].

\section{RESULTS AND DISCUSSIONS}

The study was conducted in Liliba Village, Oebobo Sub-district, Kupang City, Indonesia. The total area of the village is 1,300 hectares. Liliba Village has a population of 17,350 people with 2,771 households.

\subsection{Characteristics of respondents}

Table 1 shows the characteristics of respondents where $39.1 \%$ of them are high school graduated while $28.6 \%$ of them arehouse wives/husbands. The average income is IDR 1,975,790 where the lowest income is IDR 100,000 and highest one is IDR 5,000,000.

Table 1. Education level and occupation of the respondents

\begin{tabular}{lcc}
\hline \multicolumn{1}{c}{ Education } & $\mathrm{n}$ & $\%$ \\
\hline Elementary School & 22 & 16.5 \\
Junior High School & 17 & 12.8 \\
Senior High School & 52 & 39.1 \\
Higher Education & 42 & 31.6 \\
$\quad$ Occupation & & \\
Unemployed & 21 & 15.8 \\
House Wife/Husband & 38 & 28.6 \\
Civil Servant/Retirement/Military Forces & 33 & 24.8 \\
Merchant/Farmer/Fisherman & 16 & 12.0 \\
Entrepreneur & 25 & 18.8 \\
\hline
\end{tabular}

\subsection{Community participation}

\subsubsection{Community participation in providing bins}

Community participation in providing bins is seen through the types of bins, numbers of bins and location of bins. Table 2 shows that water proof rubbish bins are the most common ones $(81.2 \%)$. The maximum amount of rubbish bins owned by respondents istwo (45.9\%). Moreover the amount of location prepared by the respondents for the rubbish bins istwo locations $(47.4 \%)$.

\subsubsection{Community participation in sorting waste}

Table 3 shows that $89.5 \%$ of the respondents did not sorting their waste.

Table 2. Community participation in providing bins at their houses

\begin{tabular}{lcc}
\hline \multicolumn{1}{c}{ Types of bins } & $\mathrm{n}$ & $\%$ \\
\hline Not waterproof & 108 & 81.2 \\
Waterproof without a lid & 19 & 14.3 \\
Waterproof with a lid & 3 & 2.3 \\
Waterproof with a lid and easily moved & 3 & 2.3 \\
$\quad$ Total of bins & & \\
1 bin & 53 & 39.8 \\
2 bins & 61 & 45.9 \\
3 bins & 15 & 11.3 \\
More than 3 bins $\quad$ Location of bins & 4 & 3.0 \\
One spot & 50 & 37.6 \\
Two spots & 63 & 47.4 \\
Three spots & 15 & 11.3 \\
Four spots & 5 & 3.8 \\
\hline
\end{tabular}

Int. J. Public Health Sci, Vol. 9, No. 2, June 2020: 115 - 120 
Table 3. Community participation in sorting waste

\begin{tabular}{lll}
\hline \multicolumn{1}{c}{ Sorting waste } & \multicolumn{1}{c}{$\mathrm{n}$} & \multicolumn{1}{c}{$\%$} \\
\hline Sortingwaste in one bin & 119 & 89.5 \\
Sortingwaste in two bins & 13 & 9.8 \\
Sortingwaste in three bins & 1 & 0.8 \\
Sortingwaste in four bins & 0 & 0.0 \\
\hline
\end{tabular}

\subsubsection{Community participation in utilizing waste}

Table 4 shows that $66.2 \%$ of respondents did not utilize their waste.

Table 4. Utilizing waste

\begin{tabular}{lcc}
\hline \multicolumn{1}{c}{ Processing Waste } & $\mathrm{n}$ & $\%$ \\
\hline Not utilizing waste & 88 & 66.2 \\
Reusing plastic bags,etc. & 44 & 33.1 \\
Reusingplasticbagsand others or making compost & 1 & 0.8 \\
Reusing plastic bags and others, making compost, recycling & 0 & 0.0 \\
Reusing plastic bags and others, making compost, recycling and selling the recycled products & 0 & 0.0 \\
\hline
\end{tabular}

\subsubsection{Community participation in disposing waste to transfer station}

Table 5 shows the willingness of disposing waste to the transfer station while the act of not disposing rubbish to the transfer station has the highest percentage.

\subsubsection{Participation in paying waste bill}

Table 6 shows the willingness of respondents to pay waste bill and $48.1 \%$ of respondents refuse to pay the waste bill.

Table 5. Disposing waste to transfer station

\begin{tabular}{lcc}
\hline \multicolumn{1}{c}{ Disposing waste to landfills } & $\mathrm{n}$ & $\%$ \\
\hline Not disposing to transfer station & 76 & 57.1 \\
Disposing to transfer station if it is nearby & 49 & 36.8 \\
Disposing to a nearby transfer station & 4 & 3.0 \\
Disposing to a transfer station, although it is far & 4 & 3.0 \\
\hline
\end{tabular}

Table 6. Waste bill payment

\begin{tabular}{lcc}
\hline \multicolumn{1}{c}{ Waste bill payment } & $\mathrm{n}$ & $\%$ \\
\hline Not paying waste bill & 64 & 48.1 \\
Payingwaste bill according to ability to pay & 34 & 25.6 \\
Payingwaste bill as required & 35 & 26.3 \\
$\quad$ Total & 133 & 100.0 \\
\hline
\end{tabular}

\subsection{Waste production}

\subsubsection{Waste volume}

The average volume of waste was 1.8 liters/person/day.

\subsubsection{Waste characteristics}

Table 7 shows the type of waste produced by respondents, and inorganics waste is the highest waste produced by respondents.

Table 7. Waste characteristics

\begin{tabular}{lll}
\hline Types of waste & Total $(\mathrm{kg})$ & $\%$ \\
\hline Organic & 150.2 & 41.5 \\
Inorganic & 212.1 & 58.5 \\
Total & 362.3 & 100.0 \\
\hline
\end{tabular}

\subsection{Validity test and reliability indicator}

Confirmatory factor analysis was used to assess indicators that can be used to measure latent variables (valid and reliable). The parameter that can be used to assess the validity of the indicators is the value of the loading factor. The parameter used to assess the reliability indicator is the value of R 2 which is displayed in each measurement equation [12].

Table 8 show the Lisrel output. Valid and reliable indicators shown by a loading factor value and an error variance which werehigher than 0.5 with t value higher than 1.96 [12]. Indicators used to measure population characteristics were education and income. Indicators used to measure the role of the community in waste management were providing bins, sorting out organic and inorganic waste, disposing waste 
to temporary landfills, and paying waste bill. Indicators used to measure waste production were organic waste and inorganic waste.

In conclusion, the results of the validity and reliability test indicated that occupation, utilizing waste, and waste volume were variables that should be excluded from the measurement model because the values were insignificant (t-value was smaller than 1.96). So, they are invalid indicators to measure the latent variables. Of the five indicators used to measure the role of the community in waste management, providing bins was the best indicator because it had the highest loading factor value $(0.68)$.

Table 8 . The results of the confirmatory factor analysis of population characteristics

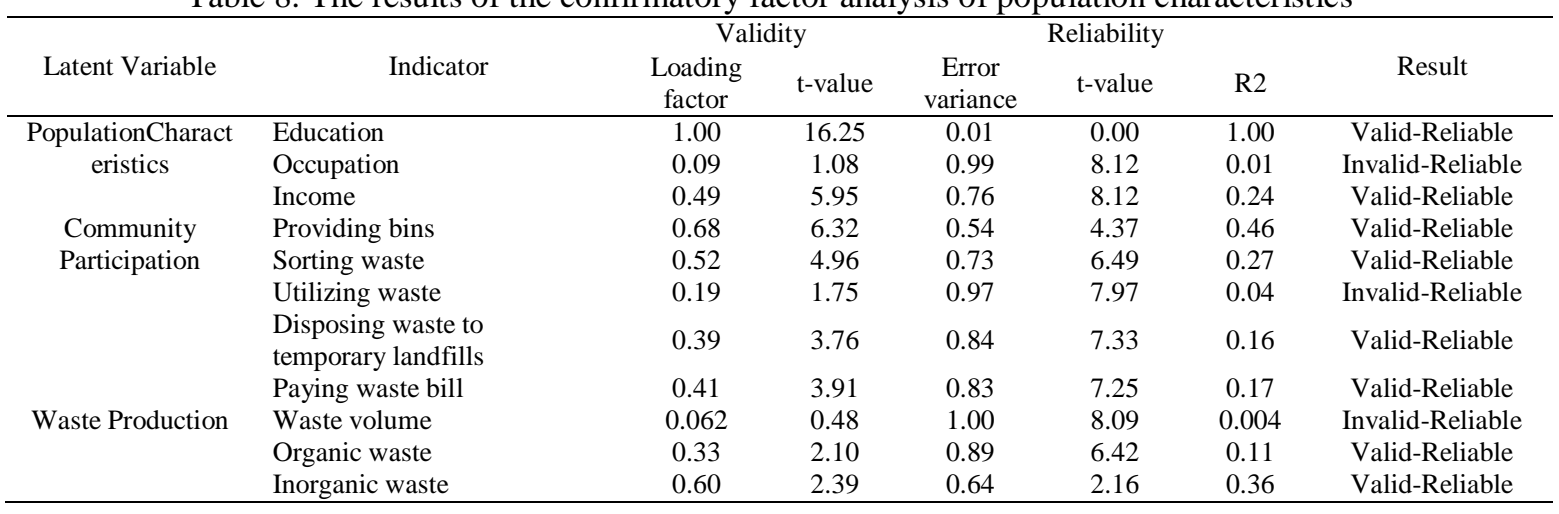

\subsection{Analysis of influence between research variables}

The pattern of relationships between latent variables in the model can be assessed using the structural equation model. The parameter that can be used to assess the strength of the relationship between latent variables is the structural coefficient, and the relationship is significant if the $t$ value is higher than 1.96 $(\alpha=0.05)$. Table 9 describes the lisrel output result and it shows that the variable of population characteristics significantly affects the variable of the role of society in managing the waste by 0.49 with $t$ value>1.96. The variable of the role of the society in managing waste significantly affects the variable of waste production by 0.52 with $t$ value $<1.96$. The variable of the characteristic of the society has a weak relation with the production of waste by 0.24 with $t$ value $<1.96$. It means that the characteristic of the society does not significantly affect the waste production, so the relation track is removed from the structural equation.

Figure 1 shows the output of path diagram, which indicates that the final model of the community's role in waste management has a p-chi-square value of 0.26088 ( $p>0.05$ ) and an RMSEA value of 0.038 $(<0.08)$, which means that this model fits (good).The population characteristics had significant direct effect on the community role variable in waste management $(0.50)$. This means thatifthe population characteristic's score is changed by one unit, it will increase the community's role by 0.50 . Likewise, the community roles in waste management had a significant direct effect on the waste production variable (0.39). This means that if community role score is changed by one unit, it will increase waste production by 0.39 .In addition, the population characteristic also had an indirect influence on waste production through the role of the community in waste management. This means that of population characteristic score is changed by one unit, it will increase waste production by 0.2 .

Table 9. Results of analysis of structural equation models

\begin{tabular}{cccc}
\hline Correlation between & $\begin{array}{c}\text { Estimated structural } \\
\text { coefficient }\end{array}$ & t-value & Result \\
\hline $\begin{array}{c}\text { Population characteristics and } \\
\text { community participation }\end{array}$ & 0.49 & 3.42 & Strong correlation-Significant influence \\
$\begin{array}{c}\text { Community participation and waste production } \\
\text { Population characteristics and waste production }\end{array}$ & 0.52 & 1.98 & Fairly strong correlation-Insignificant influence \\
\hline
\end{tabular}

\subsection{Discussion}

Population characteristics affect the role of community in waste management. Population characteristics that influence the role of the community are education level, occupation and income. These results are consistent with claims made by A. R. DarbanAstane and M. Hajilo who stated that income could affect waste production [6]. In contrast with the result of this study, Abrauw stated that the correlation of income with behavior in the management of inorganic waste is negative [13]. Education level is positively related to community participation in waste management [14]. 
The dimension of community's role in this model is valid as measured by the indicators of providing bins, sorting out waste, reusing it, disposing it to temporary landfills and paying waste bill. A study recommends that waste sorting should be done before further treatment [15]. Support from the government and educational institutions can provide opportunities to improve participation in sorting waste [16]. Waste management can also involve young people because youth with positive mind have good intentions in managing waste [17].

The indicators of utilizing waste became invalid and reliable, then, it cannot be used to measure the role of the community. This is because $90 \%$ of respondents did not utilizing waste. Organic and inorganic waste has the potential to be recycled, reprocessed and reduced as much as $35 \%$ of the volume of waste [18]. Awareness of reducing waste is increasing but the implementation of utilizing waste is still low due to lack of awareness [19]. Initiating waste collection services and building a system of sorting waste from sources can reduce the volume of waste discharged to landfills [20].

The results showed that the role of the community directly affected the waste production which means that the higher the role of the community, the higher waste production will. This happens because the indicator of utilizing waste in the dimension of community participation was invalid. If this indicator is valid, waste production can be reduced. If the variable of utilizing waste valid, the volume of inorganic waste can be reduced by $20 \%$ through the waste ban [21]. The results of the study by Surjandari et al., indicated that making compost using organic waste was effective to reduce waste by $62.5 \%$ of total waste (the amount of inorganic and organic waste). Combustion or incinerator can reduce $84 \%$ of the total waste, and the ashes of the combustion can be used for making bricks [22]. Utilizing waste into compost and selling it may reduce the volume of waste [23]. Arifiantoclaimed that the maximum utilization of waste at the source would reduce $60.94 \%$ of the waste transported to final disposal and the total reduction in greenhouse gas emissions by 203.83 tons of equivalent carbon dioxide/year [24]. Composting is one of the easiest methods to reduce the volume of organic waste [25]. This shows that good community participation must include utilizing waste. Utilizing waste can be promoted by improving knowledge and practices in household waste management [26]. Waste management training may increase knowledge, skills and motivation of citizens about independent waste management [27].

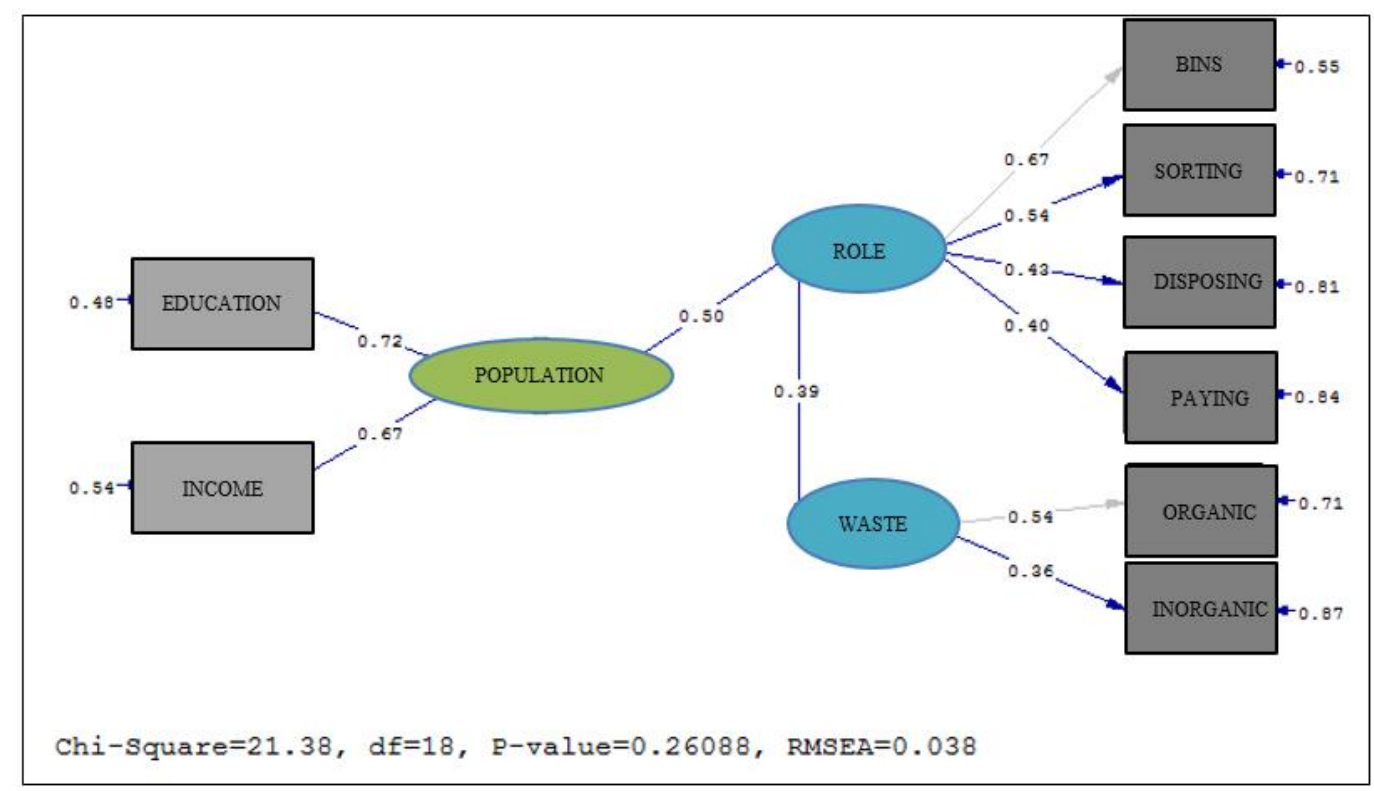

Figure 1. Path diagram of final model of structural equation

\section{CONCLUSION}

Waste management in Liliba Village requires community participation. Based on the results and discussion of waste management in Liliba Village, the characteristics of the population had a strong correlation and significant effect on the community participation. Community participation had a strong correlation and significant effect on waste production. Population characteristics had weak correlation and insignificant effect on waste production. Population characteristics significantly influenced community participation and community participation significantly influenced waste production. Participation in utilizing waste can be enhanced by some interventions such as sharing information and training. 


\section{ACKNOWLEDGEMENTS}

This research was funded by Kupang Health Polytechnic, Ministry of Health. Thanks to Yuanita Rogaleli, the enumerator who helped carry out this research.

\section{REFERENCES}

[1] Chandra Budiman, "Introduction to Environmental Health (In Bahasa Indonesia),"EGC, Jakarta, 2012.

[2] Peraturan Pemerintah Republik Indonesia Nomor 81 Tahun 2012, "Regarding the management of household waste and similar types of household waste (In Bahasa Indonesia).

[3] Mc Kenzi J. F., Pinger R. R., Kotecki J. E., "Public Health an Introduction (In Bahasa Indonesia)," Edisi 4, EGC, Jakarta, 2014.

[4] Affandy N. A., Isnaini E., Yulianti C. H., "Community Participation in Comprehensive Waste Management Towards Zero Waste (In Bahasa Indonesia)," Seminar Nasional Sainsdan Teknologi Terapan III, pp. 803-814, 2015.

[5] Nur R. S., Rudi S. D. , and Arie S.G., "Community Participation in Waste Management in Margaluyu Environment, Cicurug Village (In Bahasa Indonesia)," Share Social Work Jurnal, vol. 5, no. 1, pp. 71- 80, 2015.

[6] Darban A. R. Astane, Hajilo M., "Factors Affecting The Rural Domestic Waste Generation," Global Journal of Environmental Science Management, vol. 3, no. 4, pp. 417-426, 2017.

[7] Akhtar. S., Ahmad A.S., Qureshi M.I., Shahraz S., "Households Willingness To Pay ForImproved Solid Waste Management," Global Journal of Environmental Science Management, vol. 3, no. 2, pp. 143-152, 2017.

[8] Chapungu L., Zinhiva H., Marange N. E., "Assessment of Domestic Solid Waste Management Systemsin Rural District Service Centers: The Case of Ngangu Residential Area in Chimanimani District, Zimbabwe,"Journal of Solid Waste Technology and Management, vol. 41, no. 1, pp. 96-105, 2015.

[9] Widarjono Agus, “Applied Multivariate Statistics Analysis (In Bahasa Indonesia),”UPP STIM YKPN, Yogyakarta, 2010.

[10] Badan Standarisasi Nasional, "Methods of Taking and Measuring Examples of Incidence and Composition of urban waste (In Bahasa Indonesia)," [Online]. Available: http://sisni.bsn.go.id.

[11] Widhiarso Wahyu, "Number of Samples in Structural Equation Modeling (SEM) (In Bahasa Indonesia)," [Online]. Available: https://widhiarso.staff.ugm.ac.id.

[12] Gozhali I., Fuad, "Structural Equantum Modeling, Teori Konsep dan Aplikasi Program Lisrel 8.80," Semarang: Badan Penerbit Universitas Diponogoro, 2012.

[13] Abrauw Albert E. S., "Community Behavior in Inorganic Waste Management in Jayapura City Abepura District (In Bahasa Indonesia)," Majalah Geografi Indonesia, vol. 25, no. 1, pp. 1-14, 2011.

[14] Suffian M. Yusoff, et al., "Municipal Solid Waste Composition, Characterization And Recyclables Potential: A Case Study Evaluation In Malaysia," The Journal Solid Waste Technology and Management, vol. 44, no. 4, pp. 330-343, 2018.

[15] Seng B., Fujiwara. T., Seng B., "Suitability Assessment For Handling Methods Of Municipal Solid Waste," Global Journal of Environmental Science Management, vol. 4, no. 2, pp. 113-126, 2018.

[16] Yukalang N., Clarke B., and Ross. K, "Barriers to Effective Municipal Solid Waste Management in a Rapidly Urbanizing Area in Thailand," International Journal of Environmental Research and Public Health, vol. 14, no. 9 , pp. 1013-1026, 2017.

[17] Lin Shen, Hongyun Si, Lei Yu and Haolun Si, "Factors Influencing Young People's Intention toward Municipal Solid Waste Sorting," International Journal of Environmental Research and Public Health, vol. 16, no. 10, pp. 1708-1727, 2019.

[18] Hayana, "Socio-Economic and Cultural Relations to the Participation of Housewives in Waste Management in the District of Bangkinang (In Bahasa Indonesia)," Jurnal Kesehatan Komunitas, vol. 2, no 6, pp. 294-300, 2015.

[19] Chikere O. Aja, Dalton S. Oseghale, H.H. Al-Kayiem, "Review and Evaluation of Municipal Solid Waste Management Practices In Malaysia,” Journal Solid Waste Technology and Management, vol. 40, no. 3, pp. 215-232, 2014.

[20] Puspawati Catur, Besral, "Community Based Waste Management in Rawajati Village, South Jakarta (In Bahasa Indonesia)," Kesmas National Public Health Journal, vol. 3, no. 1, pp. 9-15, 2008.

[21] Yukalang Nachalida, Clarke Beverley, Ross Kirstin, "Solid Waste Management Solutions for a Rapidly Urbanizing Area in Thailand: Recommendations Based on Stakeholder Input," International Journal of Environmental Research and Public Health, vol. 15, no. 7, pp. 1302, 2018.

[22] Diana P., Kukuh M., and Manuwoto, "Studyof solid waste management basedon carrying capacityand storage capacity of waste infrastructures in Depok city," Journal of Regional and Rural Development Planning, vol. 2, no. 2, pp. 104-117, 2018.

[23] Surjandari I., Hidayatno A., Supriatna A., "Dynamic Model of Waste Management To Reduce Stacking Load (In Bahasa Indonesia),"Jurnal Teknik Industri-Jurnal Keilmuan dan Aplikasi Teknik Industry, vol. 11, no. 2, pp. 134-147, 2009.

[24] Sasanto R., Purwanti R., "Community Participation in Waste Management in Housing Environment Case Study: Kampung Banjar Sari Kelurahan Cilandak Barat, South Jakarta (In Bahasa Indonesia)," Jurnal Planesa, vol. 2, no. 1 , pp. 80-88, 2011.

[25] Arifianto, D. D., "Analysis of Potential Waste Reduction in Tlogomas TPS Malang City as an Effort to Reduce Global Warming (In Bahasa Indonesia)," Presiding Seminar National Pengelolaan Sumber Daya Alam dan Lingkungan, pp. 107-115, 2013.

[26] Fitria A. W., Suratman, Alifah N., Murniati T., and Catur O. P., "Knowledge and Practice in Household Waste Management,"Kesmas National Public Health Journal, vol. 13, no. 3, pp. 12-16, 2019.

[27] Kurnia Y. H, Humaedi. S, Adharani. Y, "Knowledge, Skills and Motivation of Jatiroke Villagers in Independent Waste Management (In Bahasa Indonesia)," Jurnal Pengabdian Kepada Masyarakat, vol. 2, no. 1, pp. 23-26, 2018. 